\title{
PENDIDIKAN SPIRITUAL MENUJU PEMIMPIN DAN RAKYAT YANG BERBUDI LUHUR
}

Oleh :

\author{
I Ketut Ulianta
}

\begin{abstract}
To achieve a high level of advancement and prosperity, a country needs noble leader and people. Nobility is developed and nurtured by spiritual values that people learned since the earliest time in their lives. It is in the spiritual educations where the religious and highest philosophical values are embedded.

Spiritual educational should not aim at achieving quantitative figures as the learning objective. Spiritual educational, instead, shoud be capable of internalizing the values in the inner self of the people. Once deeply internalized, the values will be genuinely reflected in the day to day behaviour of all people.

This writing highlights some of the universal value of Hindu. All of the highest values scattered in the Hindu scripture of Weda must be spreaded over and repeatedly hum to the heart of all human being. Making these values as a living guide will give rise to noble leader and society.
\end{abstract}

\section{Keywords : Spiritual Educational, Noble leader and people}

\section{Latar Belakang Masalah}

Menurunnya etika, moral, dan sensitifitas individu dan masyarakat sebagai akibat dari terjadinya verbalisme dalam pendidikan etika dan tata nilai. Pendidikan etika dan tata nilai yang cenderung mendewakan satu aspek saja dari tiga aspek yang menjadi learning outcome pendidikan yang seharusnya, baik di sisi proses maupun penilaian.

Keadaan demikian dapat menyebabkan terjadinya penyimpangan perilaku dalam berbagai segi kehidupan yang dilakukan, masyarakat, baik yang tergolong rakyat dengan perilakunya yang tidak disiplin dan memudarnya toleransi dan budaya saling menghormati. Kemudian berimbas kepada terjadinya kerusuhan maupun upaya-upaya destruktif lainya. Perilaku pejabat dalam bentuk korupsi serta pembodohan yang secara disengaja, serta tidak disiplin melakukan tugas sesuai sumpah jabatannya.

Masalah tersebut terjadi sebagai akibat menurunnya internalisasi tata nilai dalam diri insan yang merupakan elemen masyarakat. Ini dapat terjadi sebagai akibat semakin tingginya tingkat verbalisme pendidikan. Verbalisme yang dimaksud 
dimana hasil - hasil belajar hanya sebatas konsep dan teori yang dihapal tanpa dipraktekan maupun diaplikasikan. Pembiasaan menerapkan nilai-nilai yang luhur sebagai aspek afektif dari hasil belajar dalam pendidikan kita jarang dilakukan, jarang dikontrol dan kurang menjadi perhatian dalam evaluasi pembelajaran di sekolah. Penilaian hanya mementingkan nilai angka kuantitaif saja yang semestinya dikombinasi dengan nilai kualitatif. Disamping itu peran orang tua juga menurun tingkat partisipasinya untuk menanamkan nilai-nilai dasar dalam pendidikan pertama dan utama, karena terpenjara oleh waktunya yang sebagian besar dihabiskan untuk mengejar kebutuhan hidup yang harus ada sebagai tuntutan kebutuhan keluarga.

\section{Perumusan Masalah}

a. Bagaimana upaya untuk meminimalisir verbalisme dalam pendidikan etika dan tata nilai ?

b. Bagaimana meningkatkan penanaman tata nilai spritual dalam diri individu ?

c. Apa sumbangsih nilai Hindu untuk pendidikan spiritual dalam mewujudkan Pemimpin dan Rakyat yang budi luhur?

\section{Penguasaan Konsep, Internalisasi Nilai dan Penerapan dalam tindakan nyata}

Diperlukan kesadaran yang lebih terhadap penerapan konsep bahwa hasil belajar terdiri dari aspek kognitif, afektif dan psikomotor sesuai dengan pendapat Bloom, dimana semua aspek tersebut hendaknya dilatih, dibiasakan dan diperhatikan secara seimbang dalam pendidikan kita baik dalam proses pembelajarannya maupun dalam penilaiannya. Dalam proses pembelajaran, bagaimana bentuk pembelajaran maupun tugas serta kegiatan siswa diarahkan untuk dapat aktif mempraktekkan serta memahami konsep untuk pemecahan masalah dalam hidup maupun berinteraksi dengan lingkungan. Disisi penilaian hendaknya jangan terlalu mendewakan aspek kognitif, yang sangat penting justru bagaimana pengetahuan/kognitif yang telah dimiliki itu digunakannya dan diterapkannya dalam memecahkan persoalan serta berperilaku sesuai dengan tata nilai sehingga nilai-nilai yang dipahami dan dipelajari melalui konsep dapat menginternalisasi dalam dirinya yang akan digunakan untuk hidup dimasyarakat yang akan sangat menentukan kesuksesan hidup seseorang. Gadner dalam kecerdasan majemuk mengungkapkan 8 kecerdasan yang dimiliki 
individu. Kecerdasan tersebut membutuhkan peran pendidikan dalam pengembangannya. Tidak hanya kecerdasan logika-matematika, tapi banyak yang lainnya. Bagaimana individu berkomunikasi antar sesama melalui kecerdasasan linguistik, bagaimana berinteraksi dengan orang lain sesuai dengan tata nilai melalui kecerdasan interpersonal, bagaimana individu itu bertanggung jawab terhadap diri sendiri, bekerja mandiri melalui kecerdasan intrapersonal, bagaimana individu itu memahami ruang dan waktu melalui kecerdasan spasial, bagaimana individu menghargai dan mempraktekan seni, musik melalui kecerdasan musikal, melalui kecerdasan kinestetik individu memanfaatkan indera gerak dan psikomotoriknya serta melalui kecerdasan naturalis manusia menghargai dan memelihara alam.

Demikian luasnya yang perlu diperhatikan dan dikembangkan sehingga sudah seharusnya kita tidak hanya menuntut peran guru disekolah saja tetapi semua guru harus berperan baik guru di masyarakat, guru disekolah, guru dirumah maupun pemerintah dan tidak saling lempar tanggung jawab.

\section{Konsep Catur Guru Mendidik Budi Yang Luhur}

Hindu sebagai Sanatana Dharma telah mengajarkan berbagai nilai universal antara lain melalui ajaran Catur Guru yang seharusnya menjadi contoh, menanamkan nilai-nilai, memberikan pemahaman konsep-konsep yang diperlukan kepada anak didik yang belum dewasa sehingga dapat dijadikan pegangan dalam hidupnya menuju kedewasaan. Catur Guru yang dimaksud dalam Hindu adalah empat guru yang akan menuntun dan menjadi contoh bagi manusia/insani:

a. Guru Rupaka adalah Orang tua kita di rumah. Orang tua adalah orang yang harus berperan menanamkan nilai-nilai yang pertama dan utama sejak anak baru dilahirkan hingga dia menjadi dewasa. Orang tua hendaknya jangan melempar seluruhnya tanggung jawabnya kepada guru di sekolah. Karena nilai-nilai yang ditanamkan di rumah menjadi bekal untuk dibawa keluar rumah dalam berinteraksi dengan orang lain di masyarakat. Bagaimana berhadapan dengan orang yang lebih tua, bagaimana sopan santun, bagaimana bertutur kata yang benar dan baik. Kini dapat dirasakan nilai-nilai seperti ini jarang sekali menjadi perhatian orang tua terutama di kota besar, karena orang tua masing-masing terpenjara karena mengejar material untuk kebutuhan hidup. Dalam hal ini 
diperlukan mendisain ulang pengelolaan waktunya untuk si anak. Anak membutuhkan perhatian dan petunjuk dari orang tua yang mana boleh dan tidak boleh. Yang mana yang benar dan tidak benar. Juga sangat diperlukan nasehatnasehat, pitutur dan pengertian-pengertian yang minim sekali diperolehnya dari guru lain selain guru rupaka. Peran Guru rupaka/orang tua di rumah seingat penulis saat masih kecil sering dilakukan dengan metode dongeng, cerita-cerita yang mengandung petuah dan nilai-nilai luhur sehingga cenderung diminati oleh seorang anak yang belum dewasa, yang mana metode dongeng ini jarang sekali dipraktekan oleh orang tua sekarang ini. Melalui cerita, anak mendapatkan nilainilai kebenaran, pengetahuan dan perbendaharan kata, contoh-contoh kebajikan (Dharma) yang harus dijunjung tinggi, nilai kejujuran, toleransi, kerjasama, tolong menolong dan masih banyak lagi. Orang tua sudah seharusnya tidak lagi menyalahkan guru di sekolah tetapi mengevaluasi kembali dan mengambil peran masing-masing sebagai salah satu Catur Sinangguh Guru, yang harus menjadi contoh, memotivasi dan mendorong sesuai apa yang di ungkapkan oleh ki Hajar Dewantara yaitu Ing Ngarso Sung tulodo, Ing Madyo Mangun Karso dan Tut Wudi Handayani.

\section{b. Guru Pengajian}

Guru di sekolah, hendaknya jangan hanya mengajar tetapi juga mendidik seperti mengarahkan anak didik untuk bisa bersopan santun dalam bertindak dan menghadapi orang lain di masyarakat, memberi contoh perilaku yang baik. Tugas guru memang mengajarkan ilmu pengetahuan tetapi harus dihindari pembelajaran yang hanya sekedar tahu konsep melainkan agar peserta didik dapat memanfaatkan konsep tersebut untuk hidup di masyarakat. Demikian juga evaluasi terhadap padatnya kurikulum dan cara penilaian yang cenderung didominasi oleh pengetahuan kognitif. Materi pelajaran yang harus dikejar dan dihabiskan dalam proses pembelajaran karena akan diujikan melalui alat uji yang juga cenderung di dominasi oleh penilaian terhadap aspek kognitif perlu di kaji kembali, agar tersedia waktu yang lebih untuk mempraktekkan serta menginternalisasi konsep dan tata nilai yang dipelajari menjadi kompetensi pribadi yang utuh dalam diri anak didik. Mengejar materi agar habis tetapi nyatanya anak tidak memiliki kompetensi apapun. Sehingga timbulah kemampuan-kemampuan semu dimana anak hanya bisa saat akan di tes atau ujian tetapi setelahnya tidak mampu apa-apa. Untuk ini guru disekolah juga mesti 
memulai menggunakan penilaian yang sesuai dengan / valid mengukur apa yang seharusnya diukur. Tidak selalu menggunakan tes dalam menilai siswa. Instrumen penilaian hendaknya memiliki validitas yang tinggi relevan dengan aspek apakah yang ingin diketahui dari instrumen tersebut. Jika aspek kognitif yang akan dinilai memang relevan dengan menggunakan Tes tertulis, tetapi ketika hendak menilai aspek afektif lebih relevan menggunakan instrumen non tes semisal skala sikap atau pun kuesioner maupun unjuk kerja. Demikian juga untuk menilai aspek psikomotor/keterampilan anak didik lebih valid menggunakan observasi terhadap tugas yang diberikan dan anak didik haruslah melakukan sesuatu dan kita amati dengan menggunakan pedoman pengamatan/rubrik yang sudah dirancang mengenai dimensi/aspek apa yang akan kita nilai sehingga unsur subyektif dapat kita minimalisir dalam penilaian. Sudah saatnya kita mulai mengadakan evaluasi tidak hanya diakhir pembelajaran tetapi juga saat proses pembelajarn berlangsung, dan instrumen yang kita gunakan tidak melulu tes tertulis, tetapi kita sesuaikan dengan aspek tadi ibarat kalau menimbang emas janganlah menggunakan timbangan beras karena hasilnya nanti bias tidak benar/semu. Terlebih lagi dalam pembelajaran Agama yang notebena learning outcome didominasi oleh aspek afektif dan psikomotor seyogyanya penilaiannya juga lebih banyak penilaian sikap dan psikomotor adapun kognitif serta konsep-konsep yang digunakan untuk mendukung dua aspek tersebut, dengan demikian akan tercapai tujuan pembelajaran agama yang sebenarnya.

\section{c. Guru Wisesa}

Pemerintah adalah termasuk salah satu dari catur guru, hendaknya perilaku, perkataan dan pemikirannya menjadi contoh bagi rakyat. Hendaknya tidak melakukan tindakan tidak terpuji seperti korupsi, bohong, membodohi, janji-janji yang muluk, tetapi sebaliknya harus mengarahkan masyarakat atau rakyat ke hal hal yang positif. Janganlah berebut kekuasaan hanya untuk kepentingan pribadi. Guru wisesa harus mengutamakan kepentingan rakyat bukan kepentingan pribadi jika ingin berhasil menjadi guru wisesa. Ingatlah guru akan ditiru muridnya, pemerintah akan ditiru rakyatnya, rakyat meniru melanggar manakalah pemerintah sebagai guru wisesa tidak konsisten dan juga melanggar sumpah dan janjinya dalam menjalankan roda pemerintahan. Guru wisesa/pemerintah harus ingat bahwa dirinya adalah guru, yang memiliki tanggung jawab yang besar di depan menjadi teladan, ditengah memberikan motivasi dan dibelakang harus 
mampu mendorong dan menggerakkan rakyat untuk melakukan tindakan positif. Pemerintah juga tidak boleh diskriminasi terhadap kelompok-kelompok tetapi harus adil dalam memberikan perlindungan terhadap rakyat sebagai anak didiknya dalam segala bidang baik bidang pendidikan, ekonomi, agama, pelayanan, kesehatan dan lainnya. Pemerintah mendidik masyarakat melalui aturan-aturan kebijakan maupun penghargaan-penghargaan untuk memberikan motivasi serta hukuman-hukuman agar hal yang dilarang tidak dilakukan. Hukuman hendaknya yang mendidik demikian juga penghargaan yang diberikan juga mendidik. Arahan-arahan kepada masyarakat juga digunakan melalui pidato, diskusi, konferensi pers hendaknya digunakan untuk yang positif dan kepentingan anak didik/masyarakat dan bukan untuk pribadi.

\section{d. Guru Swadyaya}

Tuhan Yang Maha Esa/Sang Hyang Widhi adalah maha Guru yang memberikan tuntunan hidup manusia melalui ajaran-ajaran sucinya yang diturunkan melalui wahyu yang diterima oleh para maha Rsi/orang suci. Melalui keyakinan yang tinggi melaksanakan segala tuntunan dan menghindari semua yang tidak diperkenankan akan membawa manusia kealam pembebasan. Sradha dan Bhakti melahirkan kekuatan untuk mempelajari ajarannya, terinternalisasi dalam diri pribadi dan tercermin dalam perwujudan perilaku yang baik, jujur, kasih, sayang, tolong menolong, toleransi, tidak menghina, menghargai, menghormati, tidak menyakiti, menjauhi kekerasan atas alasan apapun, menjaga ciptaanNya.

Sinergi peran catur guru menuju pendidikan agama yang menghasilkan pribadipribadi yang tidak hanya hafal konsep-konsep, pintar kognitif, tetapi harus mampu mewujudkan dalam perilakunya dan pikirannya tentang tata nilai universal yang telah menginternalisasi dalam dirinya dan melandasi perilakunya dalam hidup bersama dan berguna bagi masyarakat manusia, alam dan seluruh ciptaanNya sehingga tercapai kedamaian disegala alam.

\section{Srada Karma Phala Mengarahkan kepada Perbuatan Baik}

Penyadaran akan adanya Karma phala kepada setiap insan dan manusia-manusia Indonesia yang membentuk bangsa ini perlu terus diupayakan. Karma Phala yang berasal dari bahasa Sansekerta yaitu Karma yang artinya Perbuatan dan Phala yang artinya Hasil sehingga secara keseluruhan artinya adalah Hasil dari Perbuatan. Setiap Insan akan menuai hasil dari perbuatannya sendiri. Perbuatan yang buruk 
(Acubakarma) memberikan hasil yang buruk pula sebaliknya perbuatan yang baik (cubakarma) juga akan memberikan hasil yang baik. Setiap insan yang berbuat tidak baik akan menerima hasil sebagai phala dari karma yang buruk dan setiap insan yang berbuat kebaikan akan menerima hasil sebagai phala dari karma yang baik. Sorga dan neraka sebagai hasil/buah atas karma-karma yang diperbuat manusia. Setiap perbuatan yang dilakukan akan membuahkan hasil baik itu hasil yang langsung didapat saat itu atau hasil yang didapatkan nanti maupun hasil yang masih sisa dari perbuatannya yang telah lalu. Semuanya akan diterima oleh insan yang bersangkutan sebagai pribadi. Kesadaran akan hal ini dapat mengarahkan setiap perbuatan insan/manusia kepada ajaran Tri Kaya Parisuda (berpikir, berkata dan berbuat yang benar) serta menjauhkannya dari Tri Mala (berpikir, berkata dan berbuat yang buruk).Tujuan akhir hidup manusia sesungguhnya bukanlah Sorga tetapi Moksa. Sorga sebagai stimulus positif untuk mengarahkan manusia untuk berbuat sesuai ajaran Dharma, berbuat Dharma dan bukan Adharma sehingga memudahkan dalam rangka mencapai tujuan akhirnya yaitu Moksa (Kebebasan Jiwa dari pengaruhpengaruh kegelapan/Awidya bersatu kembali ke asalnya yaitu Tuhan Yang Maha Esa). Neraka sebagai stimulus negatif agar manusia menghindari perbuatan yang bertentangan dengan ajaran Dharma. Jadi hukum kausalitas antara Karma dengan Phala itu bersifat inheren dan karena itu phala itu tidak dapat diminta-minta karena pasti adanya. Dan pasti ada setelah adanya karma itu.

Ulasan Upanisad tentang Sorga dan Neraka bukanlah suatu tempat dan bukan pula suatu bentuk yang pasti melainkan suatu state of mind yaitu keadaan pikiran yakni pikiran bahagia atau pikiran menderita. Kalau pikiran sedih dan menderita itulah neraka dan pikiran dalam keadaan senang dan bahagia itulah Sorga. Sorga dan Neraka ada dalam pikiran baik pikiran pada waktu masih hidup maupun pikiran yang membungkus roh sesudah mati. Roh manusia semasih hidup dibungkus oleh pikiran (suksma sarira) dan jasad/tubuh (stula sarira). Pada waktu meninggal stula sarira hancur menjadi abu karena dibakar tetapi jiwa dan pikiran tidak bisa terbakar dan lepas seperti angin dengan jiwa tetap terbungkus oleh pikiran itu sendiri (Cudamani 1989 : 94)

Suka dan duka, baik dan buruk, jauh dan dekat, benar dan salah hanya ada dalam pikiran bukan pada objek yang merupakan benda-benda di dunia ini. 
Seseorang semasa hidupnya suka mengumbar nafsu sex di tempat pelacuran, maka setelah meninggal maka roh itu memiliki keterikatan untuk datang ke tempat-tempat pelacuran dan melihat orang-orang bermain sex, roh ingin tetapi tidak bisa karena sudah tidak memiliki tubuh/jasad lagi, dia kecewa dan itulah penderitaan di alam sesudah mati. Oleh karenanya Hindu menyerukan "Lepaskanlah keterikatan terhadap benda-benda duniawi karena akan menjadi beban semasih hidup dan sesudah mati. Moksa adalah suatu istilah untuk menyebutkan kalau roh manusia telah kembali dan menjadi satu kesatuan dengan tuhan dan bebas dari keterikatan duniawi yang bebas dari kelahiran kembali yaitu kebahagiaan yang tidak lagi disusul kedukaan Inilah tujuan akhir. Dengan tujuan yang mulia ini Hindu menjadikan seni dan budaya sebagai sarana untuk berbhakti kepada Tuhan. Seni untuk membuat sejuknya hati, memperindah hidup manusia. Melalui seni manusia menjadi lembut, sehingga kecenderungan-kecenderungan pikiran yang tidak baik menjadi menurun. Hindu menuntun orang untuk mendapatkan keselamatan, mengangkat martabat manusia menjadi mahluk yang mulia, mendorong orang untuk melakukan apa yang baik untuk diri sendiri dan orang lain. Sehingga Hindu merupakan motivator, mendorong berbuat yang baik dalam kehidupan sehari-hari, merupakan dinamisator penggerak kehidupan sehari-hari, merupakan petunjuk arah dan tujuan hidup dan merupakan dasar moral manusia.

\section{Tri Hita Karana Penyadaran akan keseimbangan alam}

Tri Hita Karana berarti tiga penyebab kesejahteraan. Tri artinya tiga, Hita artinya sejahtera, Karana artinya penyebab. Tri Hita Karana mengandung pengertian tiga penyebab kesejahteraan itu bersumber pada keharmonisan hubungan antara manusia dengan Tuhannya, manusia dengan alam lingkungannya, manusia dengan sesamanya.

Unsur-unsur Tri Hita Karana ini meliputi Sanghyang Jagatkarana, Bhuana, Manusia sebagaimana terdapat dalam kitab suci Bagawad Gita (III.10), sebagai berikut:

Sahayajnah prajah sristwa pura waca prajapatih anena prasawisya dhiwan esa wo'stiwistah kamadhuk (Bagawad Gita (III.10)

Artinya

Pada jaman dahulu Prajapati menciptakan manusia dengan yadnya dan bersabda, dengan ini engkau akan berkembang dan akan menjadi kamadhuk dari keinginanmu. 
Dalam sloka Bhagavad-Gita tersebut ada nampak tiga unsur yang saling beryadnya untuk mendapatkan yaitu terdiri dari Tuhan Yang Maha Esa, Lingkungan Alam dan Manusia untuk mencapai kebahagiaan.

\section{Penerapan Tri Hita Karana.}

Penerapan Tri Hita Karana dalam kehidupan umat Hindu sebagai berikut

a. Hubungan antara manusia dengan Tuhannya yang diwujudkan dengan Dewa yadnya.

b. Hubungan manusia dengan alam lingkungannya yang diwujudkan dengan Bhuta yadnya.

c. Hubungan antara manusia dengan sesamanya diwujudkan dengan Pitra, Resi, Manusia Yadnya.

Penerapan Tri Hita Karana dalam kehidupan umat Hindu di Bali dapat dijumpai dalam perwujudan Parahyangan, yang berwujud Kahyangan Jagat, Kahyangan Tiga, dan Pemerajan sebagai tempat suci untuk menghubungan diri dengan Tuhan yang Maha Esa (Sang Hyang Widhi Wasa), Palemahan, yang diwujudkan dengan wilayah dan pekarangan rumah dan desa-desa, alam lingkungan yang harus senantiasa dipelihara kelestariannya serta Pawongan diwujudkan terpeliharanya hubungan antara umat baik tingkat wilayah, krama desa maupun tingkat keluarga.

Dengan menerapkan Tri Hita Karana secara mantap, kreatif dan dinamis akan terwujudlah kehidupan harmonis yang meliputi pembangunan manusia seutuhnya yang astiti bakti terhadap Sang Hyang Widhi Wasa/Tuhan Yang Maha Esa, cinta kepada kelestarian lingkungan serta rukun dan damai dengan sesamanya.

Penerapan ini diharapkan dapat meluas dengan penuh kesadaran dalam menjaga hubungan yang harmonis sehingga tercapai kebahagiaan dan kesejahteraan dengan mengusahakan terdengarnya nilai-nilai yang positif dan universal bagi umat manusia sehingga dapat dilaksanakan sesuai dengan ajaran sanatana dharma.

\section{Tatwam Asi Untuk menumbuhkan cinta kasih}

'Brahman Atman Aikhyam “ yang artinya Brahman (Tuhan) dan Atman adalah sama/tunggal. Atman yang menghidupkan tubuh semua makhluk hidup merupakan percikan terkecil dari Tuhan. Semua mahluk dihidupkan dari satu sumber yaitu Tuhan, oleh karenanya semua mahluk bersaudara. Menyakiti orang lain adalah juga 
menyakiti diri sendiri, menolong orang lain berarti juga menolong diri sendiri. Itulah hakekat Tat Twam Asi yang bermakna Aku adalah Engkau

Ajaran Tat Twam Asi ini mengarahkan agar kita senantiasa mengasihi orang lain atau menyayangi makhluk lain. Janganlah sekali-kali menyakiti hati orang lain, dan mahkluk lain karena pada hakekatnya semua adalah sama. Hal ini bila dihayati dan diamalkan dengan baik, maka akan terwujud suatu keharmonisan hidup (kerukunan hidup).

Makna filosofis Tat Twam Asi yang merupakan nilai-nilai universal Hindu ini sangat luas dan dalam, yang merupakan asas dari peri-kehidupan manusia. Dan jika konsep Tat Twam Asi ini sungguh dapat dipahami dan dihayati oleh setiap umat manusia tak kan ada lagi saling menyakiti antara sesama mahluk hidup karena semua ciptaan Yang Esa dan bersumber dari Brahman. Membinasakan Ciptaan Tuhan atau yang berasal dari Tuhan adalah sesungguhnya bertentangan dengan ajaran Tat Twam Asi dan sekaligus tidak memiliki rasa hormat dan bhakti kepada Tuhan sebagai penciptanya. Nilai-nilai ini harus terus didengungkan dalam rangka penyadaran umat manusia untuk tidak saling menyakiti dan membina hubunga saling asah, saling asih dan saling asuh sehingga tercipta hubungan yang harmonis didasari Dharma yang akan membawa kepada kebahagiaan di dunia dan di alam kebebasan (Moksartham Jagadita Ya Ca Iti Dharmah). Demikianlah masih banyak sekali nilai-nilai universal Hindu yang dapat digali untuk kepentingan penyadaran manusia untuk mencapai kebahagiaan.

\section{Sumbangsih Norma Agama Hindu dalam falsafah Bangsa Indonesia}

Tata nilai lazim disebut "norma", yang berasal dari bahasa Latin "norm" dan disebut "kaidah" dalam bahasa Arab (Oka Setiawan, 2013;1). Isi dari norma ini adalah berupa "perintah" yang berwujud keharusan bagi seseorang untuk berbuat atau tidak berbuat sesuatu, karena akibatnya dipandang baik. Selain itu, norma juga memuat "larangan", yang berwujud cegahan bagi seseorang untuk berbuat atau tidak berbuat sesuatu, oleh karena akibatnya dipandang tidak baik. Manfaat suatu norma adalah untuk memberi petunjuk kepada manusia bagaimana seseorang harus bertindak dalam masyarakat dan perbuatan mana yang harus dijalankan serta perbuatan mana pula yang harus dihindarkan. Setiap norma itu dipertahankan keberadaannya dengan 
sanksi yaitu ancaman atau hukuman terhadap siapa saja yang melanggar norma tersebut.

Selanjutnya Oka membedakan berbagai norma berdasarkan isi norma yang ada dan ditaati oleh manusia dalam kehidupan bermasyarakat antara lain :

a. Norma Agama : adalah aturan hidup yang diterima sebagai perintah, larangan dan anjuran yang berasal dari Tuhan Yang Maha Esa ( Hyang Widhi Wasa ) melalui perantara orang suci-Nya (nabi). Norma agama ini tidak saja mengatur hubungan manusia dengan Tuhan, tetapi juga mengatur hubungan manusia dengan manusia lainnya, bahkan mengatur hubungan manusia dengan makhluk lainnya. Contoh norma agama ini antara lain : hormatilah orang tuamu, agar engkau selamat di dunia dan di akhirat, tidak boleh berbohong, karena yang berbohong akan masuk neraka. Sanksi dari pelanggar norma agama ini didasarkan atas keyakinan terhadap agamanya itu dan akan diterima di kemudian hari atau di alam baka.

b. Norma Moral : norma ini bersumber pada hati nurani manusia. Tujuan dari norma moral ini adalah menyempurnakan manusia itu, antara lahir dan bathinnya. Sanksi yang umum diterima oleh orang yang melanggar norma moral ini sebutannya "orang itu tidak bermoral".

c. Norma Adat Istiadat : suatu norma yang sudah lama ada dalam masyarakat dan bersumber dari nenek moyang kita. Sanksi yang diterima bagi pelanggar norma adat istiadat ini berupa cemoohan dengan sebutan kata-kata "orang itu tidak beradat".

d. Norma Sopan Santun : norma ini dalam bahasa sehari-hari disebut juga "tata krama", yaitu perintah atau larangan bagi sikap masyarakat terhadap manusia lain di dalam lingkungan (masyarakat). Sanksi bagi pelanggar norma sopan santun ini, dicela dengan kata-kata "orang itu tidak punya tata krama".

e. Norma Mode : norma ini menunjukkan cara berpakaian yang sering berubahubah, sedangkan selera pribadi dikorbankan kepada norma yang ditetapkan dan diikuti oleh kelompok orang-orang tertentu. Pelanggar norma mode ini, oleh kelompoknya dianggap orang aneh (kolot / tidak gaul).

f. Norma Hukum : disebut juga "kaidah hukum", yaitu norma yang dibuat oleh penguasa Negara, karena itu disebut juga Norma Negara. Contoh norma ini antara lain : barang siapa dengan sengaja mengambil jiwa orang lain, dipidana karena 
membunuh dengan hukuman setinggi-tingginya 15 tahun (norma hukum pidana); orang yang tidak menepati janji, diwajibkan mengganti kerugian (norma hukum perdata). Keistimewaan norma hukum ini terletak pada sifatnya yang memaksa, dengan sanksi berupa ancaman hukuman. Alat-alat kekuasaan negara berdaya upaya agar norma hukum itu ditaati dan dilaksanakan. Paksaan di sini, bukan berarti sewenang-wenang melainkan harus bersifat sebagai alat yang dapat memberi suatu tekanan agar norma hukum itu dihormati dan ditaati.

Hindu sebagai agama tertua dan memiliki nilai universal dan ajaran yang luhur memberikan sumbangsih yang monumental kepada bangsa Indonesia, Salah satu sumbangsih ajaran agama Hindu yang tetap menjadi hukum bahkan falsafah bangsa Indonesia hingga kini adalah karya seorang pujangga besar Rsi Mpu Tantular berupa syair atau Kakawin (Wirama) dalam Sutasoma (Upadeca, 1989 : 34). Dalam cerita itu yang pokok digambarkannya bahwa Sang Hyang Widhi (Tuhan) adalah satu bukan dua, sekalipun ada yang mengatakan Ciwa dan Budha, syair yang dimaksud adalah :

"Rwaneka dhatu winuwus wara budha wicwa, Bhineka rakwa ringapon kena parwa nosen, mangkang jiwaktua kalawan ciwa tatwa tunggal, Bhineka tunggal ika tan hana dharma mangrwa"

Artinya : Tuhan itu dikatakan ada dua disebut Budha dan Ciwa, berbeda itu konon, namun kapan dapat dibagi dua, demikianlah kebesaran Ciwa dan Budha adalah satu, berbeda sebutan tetapi tunggal itu, tidak ada Tuhan yang dua.

Syair yang bernilai falsafah tinggi tersebut di atas, dituliskan secara singkat dengan kata-kata "Bhineka Tunggal Ika" dalam pita di kaki Burung Garuda yang merupakan lambang Negara Kesatuan Republik Indonesia (NKRI). Dengan demikian falsafah Hindu itu kini menjadi milik bangsa Indonesia yang sudah barang tentu bermanfaat bagi penduduknya yang jumlahnya sangat besar dan heterogen dan dapat dijadikan pedoman untuk menahan diri dalam menunjukkan perbedaan mencari kemenangan atas kebenaran yang berbeda-beda. (Oka Setiawan, $2013: 2$ )

\section{Pendidikan Menurut Weda}


Di dalam ajaran Agama Hindu, baik kitab suci Veda maupun susastra lainnya dikenal adanya tiga lingkungan pendidikan, yaitu keluarga, sekolah dan masyarakat (Titib, 2011 : 2). Sekolah-sekolah pada jaman Veda disebut sakha atau patasala dan pada masa belakangan dikenal dengan nama ashrama. Di Bali, di samping istilah ashrama (kini disebut pasraman) dikenal pula istilah katyagan (dari kata Bahasa Sanskerta, tyaga yang berarti tempat untuk melepaskan diri dari ikatan rumah untuk belajar di sekolah) sedang komponen yang memberikan pendidikan (pendidik) dikenal dengan sebutan "tri kang sinangguh guru" yang artinya tiga yang disebut guru. Adapun ketiga guru itu adalah guru rupaka, yang berada dilingkungan rumah yaitu orang tua, guru pangajyan (dari kata adhyaya yang artinya belajar) yaitu guru yang memberikan pendidikan formal di sekolah-sekolah, dan guru wisesa seperti pemerintah, pemuka-pemuka agama atau tokoh-tokoh masyarakat.

Kegiatan pendidikan di dalam Agama Hindu, dikenal dengan istilah "aguronguron", atau "asewakadharma". Pengertian pendidikan dalam Agama Hindu, tidak akan terlepas dari kedudukan kitab Veda sebagai sumber ajaran Agama Hindu. Oleh karena itu kitab Veda dan susastra Hindu lainnya berfungsi sebagai pedoman yang menuntun manusia dalam menjalankan kegiatan sehari-hari, termasuk dalam kegiatan pendidikan.

Dalam pendidikan kepemimpinan Agama Hindu telah menunjukan peran besarnya dalam membentuk serta melahirkan tokoh-tokoh pemimpin yang legendaris. Para pemimpin ini adalah sosok-sosok istimewa dengan cita-cita besar terhadap peradaban Hindu. Sebut saja kerajaan Majapahit dengan rajanya Hayam Wuruk dan patihnya Gajah Mada, atau di India dengan tokohnya Mahatma Gandhi dan Jawahral Nehru. Semenjak zaman prasejarah, hingga era modern tidak bisa dipungkiri Hindu memberikan warisan penting dalam konsep-konsep kepemimpinan (Sarasdewi, $2010: 2$ )

Salah satu konsep terpenting ajaran Hindu tentang kepemimpinan dapat ditemukan di dalam Nitishastra karya dari Chanakya. Nitishastra bisa dikatakan suatu karya mutakhir yang mengulas tentang pedoman-pedoman moral yang harus dipatuhi oleh seorang raja.

Sad Warnaning Rajaniti, yaitu kemampuan yang harus dimiliki seorang pemimpin. Sifat pertama adalah Abhigamika, yakni kemampuan seorang pemimpin untuk menarik hati atau simpati dari rakyatnya. Kemampuan wacana 
atau orasi dari seorang pemimpin merupakan aspek penting untuk memenangkan hati rakyat. Karena kecakapan semacam ini menunjukan semacam kharisma yang membuat rakyat dapat mempercayai pemimpinnya. Sifat kedua adalah Pradnya, yaitu seorang pemimpin harus memiliki sikap bijaksana, ia harus selalu berpikir dan bertindak bijaksana, agar dapat mengambil pilihan-pilihan yang tepat bagi rakyatnya. Sifat ketiga adalah Utsaha, ia diharuskan memiliki daya kreatifitas yang tinggi. Ia seorang visionaris yang selalu berusaha membuat inovasi-inovasi baru dalam menyempurnakan tata negaranya. Sifat keempat adalah Atma Sampad, seorang pemimpin harus tulus dan murni atmannya, segala perbuatannya harus berlandaskan atas 'good will' atau kehendak baik, selalu berpegang pada hukum-hukum Dharma. Kesadaran akan moralitas yang luhur merupakan kualitas penting seorang pemimpin yang baik. Sifat kelima adalah Sakya Samanta, yaitu kemampuan seorang pemimpin untuk menunjukan ketegasannya di hadapan para rakyatnya. Ia mampu mengendalikan para bawahannya dan memperbaiki hal-hal yang kurang sempurna di dalam sistem pemerintahannya. Sifat terakhir adalah Aksura Parisatka, bahwa seorang pemimpin harus dapat menarik kesimpulan yang bijaksana. Ia mampu mempertimbangkan berbagai macam saran-saran dari para penasehatnya dan memutuskan yang terbaik bagi pemerintahannya.

\section{Kesimpulan}

Tujuan belajar Ajaran Spritual yang murni adalah tercerminnya dalam sikap dan perilaku seluruh konsep tata nilai yang telah terinternalisasi dalam diri individu yang berawal mula belajar dari berbagai konsep-konsep Ajaran dan norma-norma yang diajarkan. Hindu memiliki berbagai ajaran nilai-nilai spritualitas yang memiliki filosofis tinggi yang mampu untuk membentuk dan melahirkan rakyat maupun pemimpin yang berbudi luhur. Konsep ajaran dan nilai yang perlu didengungkan agar terjadinya penyadaran individu untuk taat terhadap nilai spiritual yang tinggi baik nilai catur guru, karmaphala, ta twam asi, trikaya parisuda, tri hita karana, sad warnaning rajaniti dan lain sebagainya masih banyak lagi yang perlu dan belum diangkat dalam tulisan ini, sehingga nilai tersebut dapat dipelajari dan dimiliki untuk dapat diterapkan dalam kehidupan ini sehingga tercipta insan berbudi luhur. 


\section{Daftar Bacaan}

Cudamani, Pengantar Agama Hindu untuk Perguruan Tinggi, Penerbit Yayasan Dharma Sarathi, Jakarta 1989

Dharmayasa, Bhagawad Gita Nyanyian Tuhan, Penerbit Yayasan Dharma Sthapanam, Denpasar, 2013

Tirtaraharja, Umar, Pengantar Pendidikan,Penerbit Rineka Cipta, Jakarta, 2005

Triguna, Ida Bagus Gde, Mengapa Bali Unik ?, Penerbit Pustaka Jurnal Keluarga, Depok, 2011

Zuchdi, Darmiyati, Humanisasi Pendidikan, Penerbit Bumi Aksara, Jakarta, 2009

Web :

Saraswati, Dewi, Lahirnya Seorang Pemimpin, www.stahdnj.ac.id, 2010

Titib, I Made, Strategi Pengelolaan Perguruan Tinggi Hindu, www.stahdnj.ac.id, 2011. 